\title{
The effect of diets containing different levels of structural substances on morphological changes in the intestinal walls and the digestibility of the crude fibre fractions in geese (Part III)
}

\section{Dorota Jamroz, A. Wiliczkiewicz and Jolanta Skorupińska}

\author{
Department of Animal Nutrition and Feed Sciences, Wroclaw Agricultural University \\ Norwida 25/27, 50-375 Wroctaw, Poland
}

(Received 6 February 1991; accepted 29 November 1991)

\begin{abstract}
Two experiments were conducted with 270 growing geese fed complete diets differing in the source and content of carbohydrates and structural fractions. The experimental diets contained similar levels of crude fibre provided by different proportions of one of the following components: corn $(50 \%)$, dried grass $(20 \%)$, oats $(65 \%)$, beet pulp $(31 \%)$, rye $(50 \%)$, barley $(60 \%)$, field bean, pea or rapeseed meal $(20 \%$ each). The level of the crude fibre in the experimental diets was twice as high as in the control diet. The digestibilities of the structural fractions in the small and large intestine werc determined with the indicator method. Morphological changes in the walls of intestine were examined in birds slaughtered at 1 and $2 \mathrm{~h}$ after feeding.

Feeding diets containing large proportions of components rich in cellulose and hemicellulose such as oats, beet pulp and dried grass caused an increase on the thickness of the wall mainly on the muscular part of the small and large intestine. Longer villi were observed in the large intestine of birds fed the diet which contained beet pulp. Feeding a large proportion of rye containing pentosans resulted in an increase on the thickness of the mucous wall; feeding a diet containing rapeseed meal resulted in a decrease on the thickness of the intestinal wall. Small differences were found between the extent of digestion of structural substances in the two parts of the intestine. Cellulose was digested, depending on the composition of the diet, by 20 to $40 \%$, ADF by 18 do $38 \%$ and hemicellulose by 40 to $57 \%$.
\end{abstract}

KEY WORDS: geese, fibre, digestion, intestine, morphology

\section{INTRODUCTION}

High requirement of growing poultry for energy concentration and poor digestion of crude fibre are the main reasons for the use of feeds with low contents of structural substances for this category of birds. Geese are particularly interesting group of animals in this respect.

(C) Institute of Animal Physiology and Nutrition 
The source of structural substances has an important effect on the concentration of dry matter and nitrogenous compounds in the digestive tract, the length of the intestine and morphology of the intestinal walls, liver, kidney and pancreas (Brown et al., 1979; Jamroz et al., 1989; Wiliczkiewicz et al., 1987; Wiliczkiewicz et al., 1989). Geese digest structural substances better than other avian species (Drochner et al., 1988; Jamroz and Bicliński, 1975a, b; Nakahiro and Issiki, 1975: Orth, 1985; Pakulska, 1983; Thornburn and Willcox, 1965; Vogt and Stute, 1971). However, there is a scarcity of information on the processes of digestion and fermentation of the carbohydrates and crude fibre fractions. The published studies were conducted on laying hens and chicken while it seems that due to the type of feeds consumed by geese, analogies with respect to fermentation in the intestine should rather be made with pigs or rabbits (Adrian and Arnal-Peyrot, 1974; Keys et al., 1970; Laplace, 1987; Roth and Kirchgessner, 1985; Stanogias and Pearce, 1985; Żebrowska, 1985).

In order to determine the effect of structural substances on the morphology of the digestive tract and the processes of digestion in geese, a series of studies was carried out in which geese were given complete diets with large proportions of ingredients containing different fractions of carbohydrate and crude fibre (Jamroz et al., 1989; Wiliczkiewicz et al., 1987, 1989; Wiliczkiewicz, 1988). The proportions were chosen so that the amount of crude fibre in the diets was similar, and that from high fibre feeds was $100 \%$ greater than in the control diet.

\section{MATERIAI. AND METHODS}

Two experiments were conducted with 270 growing White Italian geese.

In experiment 1,2 to 5 week-old geese were assigned to five analogous feed groups and kept in roofed concrete yards. The geese were given complete diets, containing the same amount protein (approximately 17\%) but differing in the proportions of corn, dried grass, oats or dry sugar beet pulp (Table 1). The geese were slaughtered after they were 7.5 weeks old. Every four days 4 geese were selected from each group: two were slaughtered one hour after feeding, the remaining two 2 hours after feeding. The intestines were removed imnicdiately after slaughter, the particular segments tied off and their length measured. Samples for histological examination were taken from the middlc part of the small intestine, $20 \mathrm{~cm}$ from the remnant of the yolk sac and from the central part of the large intestine. They were fixed in a mixture of formaldehyde, alcohol and acetic acid. Sections were cut from the paraffin block, placed on slides, the paraffin removed and samples stained with hematoxyline and eozine. The thickness of the layers was measured using an eyepiece micrometer and the mean value was calculated from 20 measurements (Janik and Korniewic $\angle$, 1987).

The remaining birds were used for digestibility studies. The digestibilities were determined with the indicator method using $\mathrm{Cr}_{2} \mathrm{O}_{3}$ which was included at the level of $0.5 \%$ in the diet. They were fed as previously outlined and slaughtered 
TABLE 1

Composition and nutrient contents of mixtures Experiment 1

\begin{tabular}{|c|c|c|c|c|c|}
\hline \multirow{4}{*}{$\begin{array}{l}\text { Components } \\
(\%)\end{array}$} & \multicolumn{5}{|c|}{ Feeding groups } \\
\hline & I & II & III & IV & $\mathrm{V}$ \\
\hline & \multicolumn{5}{|c|}{ Mixtures with more content of: } \\
\hline & control & maize & $\begin{array}{l}\text { grass } \\
\text { meal }\end{array}$ & oats & $\begin{array}{l}\text { dried sugar } \\
\text { beet pulp }\end{array}$ \\
\hline Ground wheat & 30 & 10 & 20 & 5 & 18 \\
\hline Ground barley & 30 & 10 & 20 & 5 & 18 \\
\hline Ground maize & 7 & 50 & 19 & & - \\
\hline Ground oats & 8 & 3 & - & 65 & 6 \\
\hline Grass meal & - & - & 20 & - & - \\
\hline Dried sugar beet pulp & - & - & & & 31 \\
\hline Soya-bean oilmeal & 13 & 15 & 9 & 13 & 15 \\
\hline Meat-bone meal & 5 & 5 & 5 & 5 & 5 \\
\hline $\begin{array}{l}\text { Mineral and vitamin } \\
\text { ingredients* }\end{array}$ & 7 & 7 & 7 & 7 & 7 \\
\hline Metabolizable energy (MJ) & 11.30 & 12.33 & 10.60 & 10.62 & 11.00 \\
\hline Crude protein, $\%$ & 17.2 & 16.8 & 16.5 & 16.9 & 16.9 \\
\hline Crude fibre, $\%$ & 3.46 & 3.37 & 7.26 & 6.73 & 8.16 \\
\hline NDF, $\%$ & 14.11 & 8.97 & 19.23 & 31.02 & 24.28 \\
\hline ADF, $1 \%$ & 3.69 & 3.84 & 8.65 & 13.88 & 12.47 \\
\hline ADL, \% & 1.22 & 0.85 & 1.64 & 3.01 & 2.30 \\
\hline Hemicellulose, $\%$ & 10.42 & 5.13 & 10.58 & 17.14 & 11.81 \\
\hline Cellulose, \% & 2.47 & 2.99 & 7.01 & 10.87 & 10.17 \\
\hline
\end{tabular}

* Ingredients, \%: Dicalcium phosphate 2.0; Limestone 3.7; Salt 0.3; Premix D 1.0

after 11 days following which the contents of the ileum and large intestine were sampled. The digestibility coefficients of the crude fibre fractions according to Van Soest (1963) were determined in the small and large intestine. The chromium content in the the diets and excrements was determined by atomic absorption spectrometry (PYE Unicam SP-2300).

Experiment 2 was carried out with 120 geese. Three-weeks-old birds were assigned to 6 groups and fed complete diets (Table 2), which differed primarily on the source of structural substances (Table 1). The diets had equivalent protein contents (approx. 17\% crude protein) and similar energy values, about 11.0 $\mathrm{MJ} / \mathrm{kg}$. The geese were kept on concrete yards and fed twice daily. The amount feed given was chosen so that it was used by the next feeding. Water was given ad libitum. Six days before slaughter, $0.4 \% \mathrm{Cr}_{2} \mathrm{O}_{3}$ was added to the feed.

After the geese were 8 weeks old, 8 birds from each group were slaughtered 1 or 2 hours after feeding. The procedure after slaughter was the same as outined in 
TABLE 2

Composition and nutrient contents of mixtures

Experiment 2

\begin{tabular}{lcccccc}
\hline & \multicolumn{7}{c}{ Feeding groups } \\
\cline { 2 - 7 } \multicolumn{1}{c}{ Components } & I & II & III & IV & V & VI \\
\cline { 2 - 7 } & \multicolumn{7}{c}{ Mixtures with more content of: } \\
\cline { 2 - 7 } & control & barley & ryc & ficld & pea & rapeseed \\
& & & & bean & & oilmeal \\
\hline Ground wheat & 40 & 13 & 10 & 40 & 40 & 40 \\
Ground barley & 33 & 60 & 10 & 22 & 20 & 28 \\
Ground rye & - & - & 50 & - & - & - \\
Soya-bean oilmeal & 20 & 20 & 23 & 11 & 13 & 5 \\
Ground field-bean & - & - & - & 20 & - & - \\
Ground pea & - & $-\cdots$ & - & - & 20 & - \\
Rapeseed oilmeal & - & - & - & - & - & 20 \\
Mincral and vitamin & & & & & & \\
ingredients* & 7 & 7 & 7 & 7 & 7 & 7 \\
\hline Metabolizable energy MJ & 11.19 & 10.75 & 10.97 & 11.29 & 11.11 & 11.00 \\
Crude protein, \% & 17.15 & 17.96 & 17.09 & 17.28 & 17.09 & 17.03 \\
Crude fibre, \% & 3.98 & 4.38 & 3.37 & 4.32 & 4.07 & 5.21 \\
NDF, \% & 11.69 & 13.30 & 11.66 & 11.07 & 12.27 & 13.49 \\
ADF, \% & 3.80 & 4.29 & 3.99 & 4.35 & 4.09 & 5.93 \\
ADL, \% & 0.79 & 0.96 & 1.01 & 0.95 & 1.04 & 1.96 \\
Cellulose, \% & 3.01 & 3.33 & 2.98 & 3.40 & 3.05 & 3.97 \\
Hemicellulose. \% & 7.89 & 9.01 & 7.67 & 6.72 & 8.18 & 7.56 \\
\hline
\end{tabular}

* Ingredients, \%: Dicalcium phosphate 2.0; Limestone 3.7; Salt 0.3; Premix D 1.0

experiment 1 . In addition, samples of the pancreas and kidneys were taken in order to determine enzymatic activity.

The results pertaining to changes in wall thickness of the intestinal segments and the degree of digestion of fibre fractions in the ileum and large intestine are presented below. All of the numerical data was analyzed statistically using variance analysis and the multiple range test.

\section{RESULTS}

\section{Experiment 1}

Because of the various types of feeds given, a uniform energy value of the diets was not obtained (Table 1). In agreement with the methodological assumptions, the diets differed in their content of structural substances; the diet with the large amount of oats, followed by the beet pulp diet, had the highest hemicellulose $(17 \%)$ and cellulose $(19.8 \%)$ contents. 
Layers thickness of the small intestine wall in geese $(\bar{x} \pm s)$

Experiment 1

\begin{tabular}{|c|c|c|c|c|c|}
\hline \multirow{3}{*}{ Item } & \multicolumn{5}{|c|}{ Feeding groups } \\
\hline & 1 & II & III & IV & $\mathrm{V}$ \\
\hline & control & maize & $\begin{array}{l}\text { grass } \\
\text { meal }\end{array}$ & oats & $\begin{array}{l}\text { dried sugar } \\
\text { beet pulp }\end{array}$ \\
\hline \multicolumn{6}{|l|}{$\begin{array}{l}\text { Body mass of } \\
\text { slaughtered geese, kg }\end{array}$} \\
\hline \multicolumn{6}{|c|}{ Intestine wall with villi $(\mu \mathrm{m})$} \\
\hline & $1300^{a}$ & $1389^{a}$ & $1425^{a}$ & $1451^{b}$ & $1413^{a}$ \\
\hline & 169 & 154 & 133 & 103 & 166 \\
\hline \multirow{2}{*}{ Lenght of villi $(\mu \mathrm{m})$} & 771 & 824 & 824 & 834 & 762 \\
\hline & 94 & 142 & 146 & 148 & 140 \\
\hline \multirow[t]{2}{*}{$\%$ of wall thickness } & 59.4 & 59.1 & 57.9 & 56.7 & 54.8 \\
\hline & 2.2 & 5.0 & 5.7 & 7.1 & 5.4 \\
\hline \multicolumn{6}{|c|}{ Tunica mucosa and submucosa $(\mu \mathrm{m})$} \\
\hline & $264^{a}$ & $270^{\circ}$ & $279^{\circ}$ & $293^{a}$ & $309^{b}$ \\
\hline & 36 & 15 & 64 & 45 & 92 \\
\hline \multirow[t]{2}{*}{$\%$ of wall thickness } & 20.3 & 19.6 & 19.7 & 20.4 & 22.2 \\
\hline & 1.2 & 3.1 & 4.2 & 3.6 & 6.3 \\
\hline \multicolumn{6}{|l|}{ Tunica muscularis $(\mu \mathrm{m})$} \\
\hline & $278^{a}$ & $288^{\circ}$ & 322 & 324 & $342^{b}$ \\
\hline & 54 & 51 & 83 & 39 & 33 \\
\hline \multirow[t]{2}{*}{$\%$ of wall thickness } & $21.3^{a}$ & $20.7^{\Lambda}$ & 22.3 & 22.4 & $24.3^{\mathrm{Bh}}$ \\
\hline & 1.9 & 2.5 & 3.0 & 3.4 & 2.5 \\
\hline
\end{tabular}

A, $\mathbf{B}=\mathbf{P}<0.01$

$\mathrm{a}, \mathrm{b}=\mathrm{P}<0.05$

After 5 weeks of the experiment (Table 3 ) the geese from the following groups grew the most: control and those given the mixture of feeds with a high corn content $(3.4-5.1 \mathrm{~kg})$. The smallest gain were found in those given the beet pulp diet $(3.1-3.8 \mathrm{~kg})$. All of the birds, however, were well developed and healthy.

The thickness of the small intestine wall of the geese changed depending on the type of feed given and the time elapsing from feeding to slaughter (Table 3 ). In geese fed diets containing ground oats the intestinal wall was thicker by $12 \%$, containing dried grass and beet pulp, by $9 \%(P<0.05)$ than in the control birds. These changes were not as much the result of changes in the length of the intestinal villi (which changed from 1 to $8 \% ; \mathrm{P}<0.05$ ), but due to the changes in the thickness of the mucous and underlying membranes, which were greater in geese from groups IV and V which were fed diets containing oats and beet pulp. The thickness of the muscular wall is particular increased: it was $23 \%$ greater 
Laycrs thickness of the large intestine wall in geese $(\bar{x} \pm S)$

Experiment 1

\begin{tabular}{|c|c|c|c|c|c|}
\hline \multirow{3}{*}{ Item } & \multicolumn{5}{|c|}{ Feeding groups } \\
\hline & $\mathbf{I}$ & II & III & IV & $\mathrm{V}$ \\
\hline & control & maize & $\begin{array}{l}\text { grass } \\
\text { meal }\end{array}$ & oats & $\begin{array}{l}\text { dried sugar } \\
\text { beet pulp }\end{array}$ \\
\hline \multicolumn{6}{|c|}{ Intestine wall with villi $(\mu \mathrm{m})$} \\
\hline & $1668^{a}$ & $1677^{a}$ & $1712^{a}$ & $1615^{a}$ & $1906^{h}$ \\
\hline & 199 & 318 & 282 & 209 & 153 \\
\hline \multirow[t]{2}{*}{ Lenght of villi $(\mu \mathrm{m})$} & $634^{\mathrm{A}}$ & $687^{a}$ & $656^{\mathrm{A}}$ & $631^{A}$ & $764^{\mathrm{Hb}}$ \\
\hline & 71 & 72 & 88 & 85 & 99 \\
\hline \multirow[t]{2}{*}{$\%$ of wall thickness } & 38.1 & 40.6 & 38.5 & 39.2 & 40.2 \\
\hline & 2.4 & 2.6 & 2.3 & 2.2 & 3.2 \\
\hline \multicolumn{6}{|c|}{ Tunica mucosa and submucosa $(\mu \mathrm{m})$} \\
\hline & $245^{\mathrm{A}}$ & $237^{\mathrm{A}}$ & $262^{a}$ & $240^{\mathrm{A}}$ & $305^{\mathrm{B} b}$ \\
\hline & 17 & 27 & 20 & 33 & 30 \\
\hline \multirow[t]{2}{*}{$\%$ of wall thickness } & 14.7 & 14.3 & 15.6 & 14.8 & 16.1 \\
\hline & 1.8 & 2.1 & 2.2 & 0.5 & 2.8 \\
\hline \multicolumn{6}{|c|}{ Tunica muscularis ( $\mu \mathrm{m})$} \\
\hline & 788 & 753 & 794 & 745 & 831 \\
\hline & 71 & 72 & 88 & 85 & 99 \\
\hline \multirow[t]{2}{*}{$\%$ of wall thickness } & 47.1 & 44.9 & 45.5 & 45.9 & 43.7 \\
\hline & 2.7 & 1.5 & 3.3 & 3.2 & 1.8 \\
\hline
\end{tabular}

$\mathrm{A}, \mathrm{B}=\mathbf{P}<0.01$

$\mathrm{a}, \mathrm{b}=\mathbf{P}<0.05$

$(\mathrm{P}<0.05)$ in birds fed the diet containing beet pulp and $16 \%$ in those given ground oats and dried grass.

The length of time from feeding to slaughter also affected the thickness of the small intestine wall, which averaged $1464 \mu \mathrm{m}$ after 1 hour and $1362 \mu \mathrm{m}$ after 2 hours $(\mathrm{P}<0.05)$. The decrease of the villi layer with time after slaughter was highly significant $(\mathrm{P}<0.01)$ - from 927 to $747 \mu \mathrm{m}$, while that of the mucous membrane and muscular wall to a lesser degree $(\mathrm{P}<0.05)$.

The components of the crude fibre fractions had a lesser effect on the thickness of the large intestine (Table 4). Only when beet pulp was fed to the geese (31\% content) did the wall of this intestine increase by $14 \%(\mathrm{P}<0.05)$, and the length of the villi and thickness of the mucous and underlying membrane by $20-24 \%$ $(\mathrm{P}<0.01)$ in comparison with respective values in control birds. Other studies have, however, demonstrated the distinct effect of ground barley on increasing the intestinal wall (Jamroz, 1990). 
TABLE 5

Coefficients of digestibility of fibre fractions (in \%) in ileum and large intestine ( $\bar{x} \pm s)$

Experiment 1

\begin{tabular}{|c|c|c|c|c|c|c|}
\hline \multirow{3}{*}{ Ingredients } & \multicolumn{4}{|c|}{ Feeding groups } & \multicolumn{2}{|c|}{ Time after feeding } \\
\hline & I & 11 & III & IV & \multirow[b]{2}{*}{$1 \mathrm{~h}$} & \multirow[b]{2}{*}{$2 h$} \\
\hline & control & $\begin{array}{l}\text { grass } \\
\text { meal }\end{array}$ & $\begin{array}{l}\text { ground } \\
\text { oats }\end{array}$ & $\begin{array}{l}\text { sugar beet } \\
\text { pulp }\end{array}$ & & \\
\hline \multicolumn{7}{|c|}{ Ileum } \\
\hline NDF & $\begin{array}{c}43.8^{a} \\
8.5\end{array}$ & $\begin{array}{l}46.6^{a} \\
11.7\end{array}$ & $\begin{array}{r}41.3 \\
6.4\end{array}$ & $\begin{array}{c}31.9^{b} \\
5.1\end{array}$ & $\begin{array}{c}38.3^{a} \\
8.3\end{array}$ & $\begin{array}{l}43.6^{a} \\
10.1\end{array}$ \\
\hline $\mathrm{ADF}$ & $\begin{array}{c}18.2^{\mathrm{A}} \\
6.9\end{array}$ & $\begin{array}{c}36.6^{\mathbf{B} a} \\
8.0\end{array}$ & $\begin{array}{r}28.8^{b} \\
7.7\end{array}$ & $\begin{array}{c}24.1^{\mathrm{A}} \\
2.8\end{array}$ & $\begin{array}{c}23.7^{a} \\
5.7\end{array}$ & $\begin{array}{l}30.1^{a} \\
11.2\end{array}$ \\
\hline Cellulose & $\begin{array}{c}19.7^{\mathrm{Aa}} \\
5.3\end{array}$ & $\begin{array}{c}38.7^{\mathbf{B}} \\
8.3\end{array}$ & $\begin{array}{c}31.5^{b} \\
8.2\end{array}$ & $\begin{array}{c}20.1^{\mathrm{A} u} \\
2.6\end{array}$ & $\begin{array}{r}25.4^{u} \\
5.3\end{array}$ & $\begin{array}{l}29.6^{a} \\
13.5\end{array}$ \\
\hline Hemicellulose & $\begin{array}{l}52.8^{a} \\
11.5\end{array}$ & $\begin{array}{l}54.8^{a} \\
14.8\end{array}$ & $\begin{array}{r}51.5^{a} \\
7.4\end{array}$ & $\begin{array}{c}40.2^{a} \\
8.6\end{array}$ & $\begin{array}{l}46.9^{a} \\
11.9\end{array}$ & $\begin{array}{l}52.8^{a} \\
11.4\end{array}$ \\
\hline \multicolumn{7}{|c|}{ Large intestine } \\
\hline NDF & $\begin{array}{r}44.6 \\
6.4\end{array}$ & $\begin{array}{r}45.8 \\
7.2\end{array}$ & $\begin{array}{r}44.9 \\
4.7\end{array}$ & $\begin{array}{r}32.3 \\
3.6\end{array}$ & $\begin{array}{r}39.5 \\
2.6\end{array}$ & $\begin{array}{r}44.7 \\
9.4\end{array}$ \\
\hline $\mathrm{ADF}$ & $\begin{array}{r}18.6 \\
8.4\end{array}$ & $\begin{array}{r}38.2 \\
8.3\end{array}$ & $\begin{array}{r}37.7 \\
6.4\end{array}$ & $\begin{array}{r}25.2 \\
2.6\end{array}$ & $\begin{array}{r}29.3 \\
4.2\end{array}$ & $\begin{array}{l}30.6 \\
15.2\end{array}$ \\
\hline Cellulose & $\begin{array}{l}23.3 \\
17.1\end{array}$ & $\begin{array}{r}40.4 \\
8.7\end{array}$ & $\begin{array}{r}41.4 \\
4.0\end{array}$ & $\begin{array}{r}22.2 \\
2.8\end{array}$ & $\begin{array}{r}33.1 \\
5.9\end{array}$ & $\begin{array}{l}30.3 \\
17.6\end{array}$ \\
\hline Hemicellulose & $\begin{array}{r}57.1 \\
6.9\end{array}$ & $\begin{array}{r}51.9 \\
6.3\end{array}$ & $\begin{array}{r}50.7 \\
3.3\end{array}$ & $\begin{array}{r}41.8 \\
4.8\end{array}$ & $\begin{array}{r}48.3 \\
2.9\end{array}$ & $\begin{array}{l}52.4 \\
10.1\end{array}$ \\
\hline
\end{tabular}

$A, B=P<0,01$

$\mathrm{a}, \mathrm{b}=\mathrm{P}<0,05$

The type of feed dominating in the diet had an influence on the digestibility of the crude fibre fractions in the ileum (Table 5). Cell wall components (NDF and ADF) were digested best from diets containing a high proportion of dried grass, worse from those containing beet pulp $(\mathbf{P}<0.05$ and $\mathbf{P}<0.01)$. Cellulose was best digested from dicts with a $20 \%$ content of dried grass $(39 \%)$ and with a $65 \%$ content of ground oats $(31 \% ; \mathrm{P}<0.05)$. The digestibility coefficients for hemicellulose did not significantly differ among the groups, but were lower in the birds fed the diet containing beet pulp $(\mathrm{P}<0.05)$. The digestibility coefficients for structural substances in the small intestine determined 2 hours after feeding were higher by $4-7$ units than after the first hour $(P<0.05)$.

The digestibility coefficients of fibre fractions, calculated on the basis of the large intestine contents, did not differ to significant degree from respective values 
determined in the ileum. The differences among the groups in the degree of digestion of NDF and ADF fractions equalled 1-12 units. The digestibility coefficients of cellulose were clearly higher and ranged from 22 to $41 \%$. In this part of the intestine the diet containing beet pulp was also digested more poorly. In spite of rather large differences among groups, they were not proved statistically, which was caused by high individual variability. This fact has also been pointed out by other authors (Jamroz and Bieliński, 1975a, b; Pakulska, 1983). The digestibility of structural substances in the large intestine was 4-6 units higher in the second than in the first hour after feeding $(P<0.05)$.

\section{Experiment 2}

The mean weight of the geese at slaughter was $3.1-3.7 \mathrm{~kg}$, body gain was greatest in the geese fed diets containing rapeseed oilmeal and pea (Table 6).

Layers thickness of small intestine wall in geese $(\bar{x} \pm s)$

TABLF 6 Experiment 2

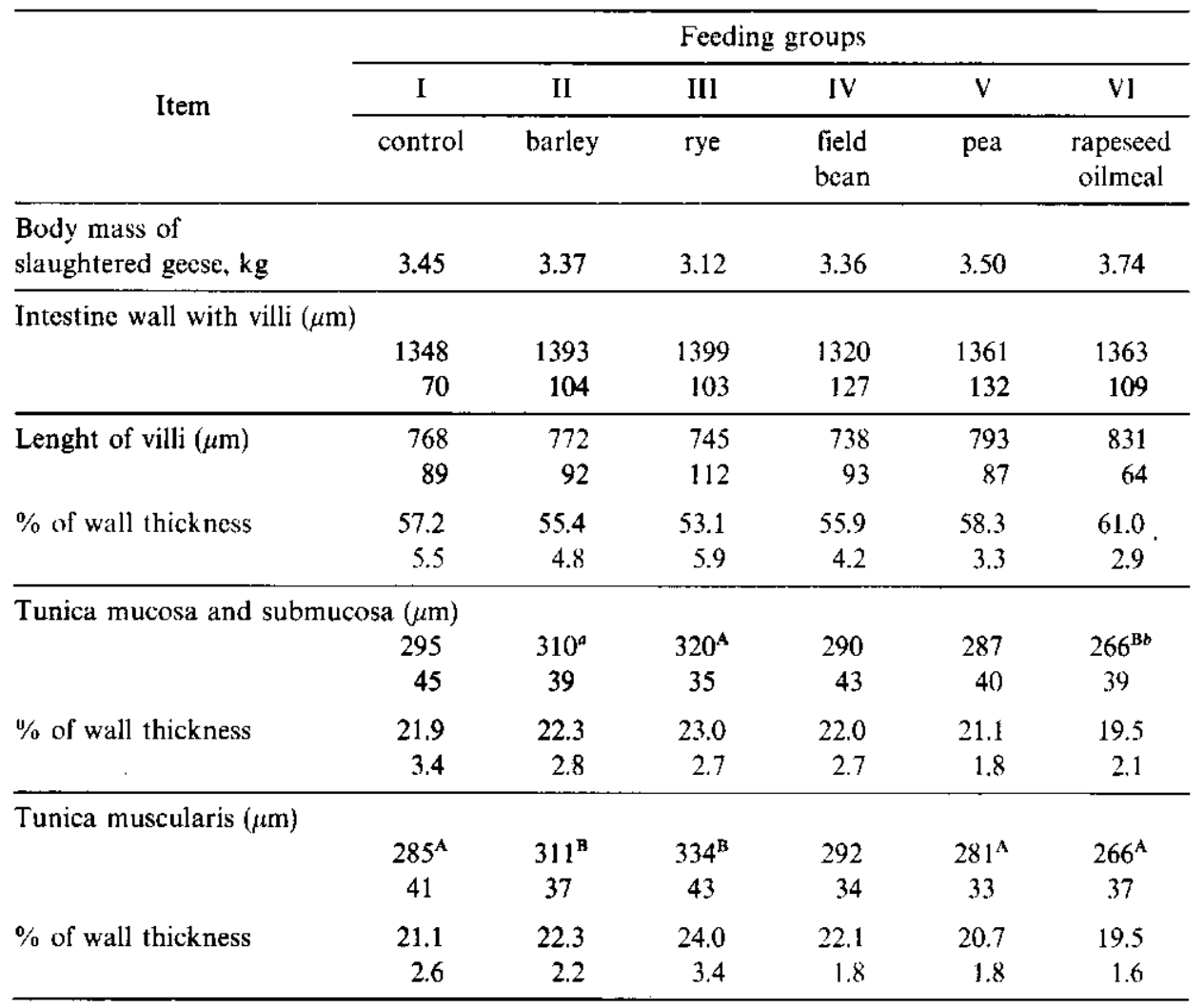

$\mathrm{A}, \mathrm{B}=\mathrm{P}<0.01 \quad \mathrm{a}, \mathrm{b}=\mathrm{P}<0.05$ 
The introduction into the diets of large amounts of feeds containing anti-nutritive factors and of various proportion of carbohydrates did not cause large differences in the thickness of the walls of the small intestine (up to a maximum of $3.8 \%$ ). Similarly, small differences were found in villi length, although feeding the diet containing $20 \%$ rapeseed oilmeal did cause an $8 \%$ increase in their length in comparison with the geese from the control group $(\mathrm{P}<0.05)$.

Consumption of a diet containing large amount of rye $(50 \%)$ caused only a $3.8 \%$ thickening of the intestinal wall; on feeding a diet with rapeseed oilmeal the intestinal wall thickness decreased by $10 \%$ in comparison with analogous values in control geese. A high rye content in the diet caused a $17 \%$ $(\mathrm{P}<0.05)$ increase in the thic kness of the muscular wall of the small intestine; the effect of the barley was somewhat less marked, in spite of this, the difference between the muscular wall thickness in these birds and the control was $9 \%$ $(\mathrm{P}<0.01)$. The opposite effect of feeding large amount of barley on the mucous membrane and muscular wall of the small intestine (that is, a distinct increase in wall thickness) was found in chickens (Jamroz et al., 1990).

The digestibility coefficients of crude fibre fractions determined on the basis of the compositions of the contents of the ileum were statistically different depending on the type of diet fed (Table 7). The NDF fraction, including cellulose, was best digested from diets containing rapeseed oilmeal or field bean $(\mathrm{P}<0.01)$. The effects of antinutrient factors occurring in rye, field bean, pea and rapeseed oilmeal were not evident in terms of digesting structural substances. Hemicellulose were digested to a significant degree (52-66\%). Similar coefficients were obtained by Pakulska (1983). In this experiment too, in which diets composed only of

\section{TABLE 7}

Coefficients of digestibility of fibre fractions in ileum, $\%(\bar{x} \pm s)$

\begin{tabular}{|c|c|c|c|c|c|c|c|c|}
\hline \multirow{3}{*}{ Ingredients } & \multicolumn{6}{|c|}{ Feeding groups } & \multirow{2}{*}{\multicolumn{2}{|c|}{$\begin{array}{c}\text { Time after } \\
\text { feeding }\end{array}$}} \\
\hline & \multirow{2}{*}{$\frac{\mathrm{I}}{\text { control }}$} & \multirow{2}{*}{$\frac{\text { II }}{\text { barley }}$} & \multirow{2}{*}{$\frac{\text { III }}{\text { rye }}$} & \multirow{2}{*}{$\begin{array}{l}\text { IV } \\
\text { field } \\
\text { bean }\end{array}$} & \multirow{2}{*}{$\frac{\mathrm{V}}{\text { pea }}$} & \multirow{2}{*}{ 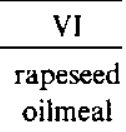 } & & \\
\hline & & & & & & & $1 \mathrm{~h}$ & $2 \mathrm{~h}$ \\
\hline NDF & $\begin{array}{c}39.5^{a} \\
2.8\end{array}$ & $\begin{array}{c}46.0^{a} \\
3.5\end{array}$ & $\begin{array}{l}48.3^{a} \\
12.5\end{array}$ & $\begin{array}{l}44.2^{a} \\
12.0\end{array}$ & $\begin{array}{c}41.7^{\circ} \\
3.2\end{array}$ & $\begin{array}{c}50.5^{a} \\
8.2\end{array}$ & $\begin{array}{r}42.5^{a} \\
7.0^{\circ}\end{array}$ & $\begin{array}{r}47.6^{\circ} \\
8.7\end{array}$ \\
\hline ADF & $\begin{array}{c}13.4^{\mathrm{Aa}} \\
5.0\end{array}$ & $\begin{array}{c}16.5^{\mathrm{Aa}} \\
6.5\end{array}$ & $\begin{array}{c}13.8^{\mathrm{A} a} \\
5.4\end{array}$ & $\begin{array}{c}27.0^{b} \\
9.9\end{array}$ & $\begin{array}{c}17.6^{\mathrm{A} a} \\
7.9\end{array}$ & $\begin{array}{c}31.0^{\mathrm{B}} \\
9.5\end{array}$ & $\begin{array}{c}15.9^{\mathrm{A}} \\
7.1\end{array}$ & $\begin{array}{l}23.9^{\mathrm{B}} \\
10.3\end{array}$ \\
\hline Cellulose & $\begin{array}{c}15.2^{\mathrm{A}} \\
6.4\end{array}$ & $\begin{array}{c}18.4^{\mathrm{AB}} \\
6.2\end{array}$ & $\begin{array}{c}17.0^{\mathrm{AB}} \\
6.2\end{array}$ & $\begin{array}{c}30.6^{\mathrm{BC}} \\
9.6\end{array}$ & $\begin{array}{c}20.9^{a} \\
7.0\end{array}$ & $\begin{array}{l}34.2^{C b} \\
11.5\end{array}$ & $\begin{array}{c}18.8^{a} \\
7.3\end{array}$ & $\begin{array}{l}26.6^{\mathrm{b}} \\
11.4\end{array}$ \\
\hline Hemicellulose & $\begin{array}{c}52.0^{a} \\
6.5\end{array}$ & $\begin{array}{c}60.3^{a} \\
6.8\end{array}$ & $\begin{array}{l}66.2^{a} \\
18.4\end{array}$ & $\begin{array}{l}55.4^{u} \\
16.4\end{array}$ & $\begin{array}{c}53.8^{\circ} \\
4.5\end{array}$ & $\begin{array}{l}65.7^{a} \\
12.6\end{array}$ & $\begin{array}{c}57.2^{a} \\
9.7\end{array}$ & $\begin{array}{l}60.6^{a} \\
14.4\end{array}$ \\
\hline
\end{tabular}

$\mathrm{A}, \mathrm{B}=\mathrm{P}<0.01$
$\mathrm{a}, \mathrm{b}=\mathrm{P}<0.05$ 
TABLE 8

Pancreas and kidney enzymes activity $(\overline{\mathrm{x}} \pm \mathrm{s})$

\begin{tabular}{lrrrrrr}
\hline \multirow{2}{*}{ Item } & \multicolumn{5}{c}{ Feeding groups } \\
\cline { 2 - 7 } & \multicolumn{1}{c}{ I } & II & III & IV & V & VI \\
\cline { 2 - 7 } & control & barley & rye & $\begin{array}{r}\text { field } \\
\text { bean }\end{array}$ & pea & $\begin{array}{r}\text { rapeseed } \\
\text { oilmeal }\end{array}$ \\
\hline Pancreas alpha amylase & & & & & & \\
ukat/mg protein & 8.29 & 7.53 & 8.17 & 10.25 & 7.86 & 10.45 \\
& 3.05 & 1.38 & 1.84 & 4.26 & 2.56 & 4.04 \\
\hline Pancreas protein mg/ml & 14.43 & 13.35 & 13.01 & 13.78 & 13.29 & 14.08 \\
& 2.97 & 1.87 & 2.45 & 2.57 & 3.56 & 2.95 \\
\hline Kidney enzyme activity & & & & & & \\
i.u./mg protein & & & & & & \\
\multicolumn{1}{c}{ LAP } & 84.21 & 82.78 & 89.20 & 99.58 & 80.69 & 86.36 \\
\multicolumn{1}{c}{ GGT } & 33.87 & 34.00 & 19.34 & 31.47 & 20.78 & 32.66 \\
& 16.41 & 16.38 & 18.13 & 22.30 & 18.90 & 14.83 \\
\hline Kidney protein mg/ml & 4.10 & 5.51 & 4.90 & 4.84 & 4.72 & 4.53 \\
\hline & 17.08 & 18.79 & 16.98 & 15.59 & 15.45 & 16.25 \\
& 3.94 & 5.08 & 4.86 & 2.19 & 4.01 & 3.53 \\
\hline
\end{tabular}

LAP - leucyloaminopeptydase

GGT - glutamyloaminotransferase

concentrates were provided, the digestibility of structural components 2 hours after feeding geese was greater than after 1 hour $(\mathrm{P}<0.05$ and 0.01$)$.

The increase in the activity of alpha-amylase in the pancreas of the geese fed diets containing field beans and rapeseed meal diet was 23 to $26 \%$ compared to the control diet; a diet containing a large proportion of barley caused a decrease in the activity of this enzyme by $9 \%$ (Table 8 ). A high barley content caused a decrease in the activity of this enzyme in the pancreas by $9 \%$. Feeding a diet containing field bean caused an 18 and $36 \%$ increase in the enzymes LAP and GGT in the kidneys, while that of GGT by feeding geese a diet containing pea and rye. In spite of distinct differences between groups, their statisitical significance was not proved.

\section{DISCUSSION}

The variety of structural components in the feeds used in experiment 1 clearly modified the thickness of intestinal walls. Giving complete diets containing large proportions of ground oats $(65 \%)$ and beet pulp $(31 \%)$, as well as dried grass, that is - hemicellulose, cellulose and pectins, caused an increase in the thickness 
of the small and large intestinal walls; in the case of the small and large intestine this was due mainly to the thickening of the muscular wall (from 16 to $23 \%$ ). The changes in the large intestine were mainly associated with increases in the length of the villi, which were significant in the geese which were fed beet pulp in the diet $(\mathrm{P}<0.01)$.

The thickness of the particular layers of the small intestinal wall was from 1339 to $1464 \mu \mathrm{m}$, the villi from 726 to 917 , the mucous membrane from 247 to 313 and of the muscular wall from 289 to $312 \mu \mathrm{m}$, with the villi constituting $54-62 \%$ of the wall thickness. In the large intestine the villi constituted only $39 \%$ and muscular layer $45-47 \%$ of the wall thickness.

Concentrate, which were used in larger amounts in the diets given to geese in experiment 2, that is barley, rye, field bean, pea and rapeseed oilmeal had a smaller effect on intestinal wall thickness, although some of the differences between the groups were statistically significant. When feeds containing large amount of rye were given, thickening of the mucous membrane was observed, when rapeseed meal was fed a significantly thinner small intestinal wall was found $(\mathrm{P}<0.01)$. In spite of the highest hemicellulose and cellulose content in diets with barley, rye and pea, no essential changes in the morphology of the intestinal wall in comparison with the control group were observed.

Similar changes were found in the thickness of the muscular wall. It may be supposed that when young geese are fed feeds rich in structural carbohydrates, the structure of these substances (eg. pectins in oats and beet pulp) may have a mechanical effect on the intestinal wall (Adrian and Arnal-Peyrot, 1974;

TABLE 9

Average digestible coefficients of fibre fractions in ileum and large intestine (\%) Experiment 1

\begin{tabular}{lcccccc}
\hline \multirow{2}{*}{ Item } & \multicolumn{5}{c}{ Feeding groups } \\
\cline { 2 - 7 } & $\begin{array}{l}\text { control } \\
\text { mixture }\end{array}$ & $\begin{array}{c}\text { grass } \\
\text { meal }\end{array}$ & $\begin{array}{c}\text { ground } \\
\text { oats }\end{array}$ & $\begin{array}{c}\text { dricd sugar } \\
\text { beet pulp }\end{array}$ & $1 \mathrm{~h}$ & $2 \mathrm{~h}$ \\
\hline ADF & 18 & 36 & 29 & 24 & 24 & 30 \\
$\quad$ ileum & 18 & 38 & 38 & 25 & 29 & 30 \\
large intestine & 20 & 39 & 31 & 20 & 25 & 29 \\
Cellulose & 23 & 40 & 41 & 22 & 33 & 30 \\
$\quad$ ileum & & & & & & \\
large intestine & 53 & 55 & 51 & 40 & 47 & 53 \\
\hline Hemicellulose & 57 & 52 & 51 & 42 & 48 & 52 \\
ileum & & & &
\end{tabular}


Brown et al., 1979; Drochner et al., 1988; Orth, 1985; Wiliczkiewicz et al., 1987, 1989, Wiliczkiewicz, 1988), while giving feeds containing antinutrient factors (eg. in rye) played a part in the changes in the thickness of the walls, their hypertrophy and softening.

A comparision of the digestibility coefficients of some fractions of crude fibre, determined in the contents of the ileum and large intestine, points to the high degree of digestion of these substances in both parts of the intestine (Table 9). An exception to this is, ADF and cellulose from oats. The role of the large intestine in the digestion of crude fibre fraction coming from other feeds seems to be less important. In the determination of digestibility coefficients in the ileum, the effect of time elapsing from feeding the birds was significant, with the differences in the value of these coefficients reaching 4 to 7 units, that is, $15-25 \%$. Respective differences in the digestibility coefficients determined in the large intestine amounted only by $1-4$ units, which may indicate that time function was here less important.

The interpretation of these facts is not simple and unequivocal, because the degree of digestion of crude fibre fractions may be the result of the physical and chemical structure of these substances, the degree of water binding by the feeds used and the rate of passage in the intestines. It is also necessary to study the rate and degree to which the digesta passes to the caeca. Their role in the process of digestion in geese has not yet been well understood. The swelling of pectins can lead to dehydration and damage to the villi, which has been found in earlier studies (Jamroz et al., 1989).

The geese best digested the structural substances from diets made up of $65 \%$ ground oats, $20 \%$ field bean or rapeseed meal in spite of the fact that these diets contained more lignin, cellulose and hemicellulose than diets with beet pulp. Similarly high digestibility was found on feeding a diet containing $20 \%$ dried grass, lower when the geese were fed the control diet or one containing $50 \%$ corn. This information is also important for breeders. Dry beet pulp, which is given often to young geese, not only decreased gains and the degree of digestibility of fibre fractions, but also caused the greatest changes in intestinal walls (hypertrophy of the muscular wall) while when oats were given, the mucous membrane, which plays an important role in the absorption of nutrients, thickened. The increase in the thickness of the muscular wall was caused by the large proportion of rye and barley in the diet while the thinning of the mucous membrane - by repeseed meal. Such a specific effect of feeds on the intestine wall may significantly modify the degree of absorption of nutrients, which requires further studies.

\section{REFERENCES}

Adrian J., Arnal-Peyrot P., 1974. Metabolisme des pentosanes de cerèales chez le monogastrique. C.R. Acad. Sci. Agric. Fr, 60, 1153-1157.

Brown R.C., Kellner M.S., Kosovsky M.S., 1979. The effect of pection on the rat small intestine. Br. J. Nutr., 42, 357-365. 
Drochner W., Romruen K., Luders H., Gunter K.D., 1988. Negativwirkung oraler Pektinzulagen auf verdauungsphysiologische Parameter des Legehenne. Vortr. zur 42. Tagung in Göttingen.

Jamroz D., Bieliński K., 1975a. Współczynniki strawności nicktórych pasz stosowanych w żywieniu gęsi. Zesz. Nauk. AR Wrocław, Zoot. XXI. 112, 105-120.

Jamroz. D., Bieliński K., 1975b. Strawność składników pokarmowych dawek dla gęsi w zależności od poziomu włókna surowego. Zesz. Nauk. AR Wrocław, Zoot. XXI, 112, 121-135.

Jamroz D., Wiliczkiewicz A., Skorupińska J., Sobiech K., Madej J., 1991. Wpływ pasz o różnej zawartości substancji strukturalnych na przewód pokarmowy i trawienie u rosnących gęsi. II. Aktywność enzymatyczna trzustki i surowicy oraz zmiany morfologiczne narządów wewnętrznych i jelit. Rocz. Nauk Rol. Ser. B-107, 1-2, 98-114

Jamroz D., Schleicher A., Wiliczkiewicz. A., Skorupińska J., 1990. Interakcja miçdzy rodzajem stosowanego antybiotyku paszowego a składem mieszanek treściwych i jej wplyw na biochemiczne i morfotyczne wskaźniki krwi oraz histologiczne zmiany w ścianje jelita cienkiego u kurcząt rzeżnych. Rocz. Nauk. Zoot. (in press).

Janik K., Kornicwicz A., 1987. Wplyw rumensinu i salinomycyny na ścianę jelita cicnkiego tuczonych jagniąt. Rocz. Nauk. Zoot. Monogr. Rozpr., 25, 89-100.

Keys J.E., Van Soest P.J., Young E.P., 1970. The effect of increasing dietary cell-wall content on the digestibility of hemicellulose and cellulose in swine and rats. J. Anim. Sci., 31, 1172-1177.

Laplace J.P., 1987. Le transit digestif chez les monogastriques. Ann. Zoot., 27, 225-265.

Nakahiro J., Issiki J., 1975. Effect of caecal ligation on digestibility of crude fibre, cellulose and pentosans in chicken. Jap. Poultry Sci., 12, 138-140.

Orth H., 1985. Einfluss steigender Pektinzulangen in der Diät auf Legeleistung und Verdaulichkeit der Rohnärstoffe bei Legehennen. Thesis. Hannover.

Pakulska E., 1985. Trawienie pektyn oraz nicktórych frakcji włókna u gesi. Thesis. Kraków.

Roth F.X., Kirchgessner M., 1985. Verdaulichkeit und intestinale Passagerate beim Schwein in Abhangigkeit von Futterungsniveau und Rohfassereghalt des Futters. Z. Tierphysiol. Tierernähr. Futtermittelk., 53, 254-264.

Stanogias G., Pearce G.R., 1985. The digestion of fibre by pigs. 3. Effects of amount and type of fibre on physical characteristes of the gastrointestinal tract. Br. J. Nutr., 53, 537-548.

Thorburn C.C., Willeox J.S., 1965. The caeca of the domestic fowl and digestion of the crude fibre complex. Br. Poultr. Sci., 6, 33-43.

Van Soest P.J., 1963. A rapid method for the determination of fiber and lignin. J. Assoc. Agric. Chem., 46, 829-835.

Vogt H., Stute K., 1971. Uber die Verdaulichkeit einiger Kohlenhydratfraktionen (Zucker, Stärke, Pentozan, Rohcellulose, Lignin) in IJuhnerfutter. Arch. Geflügelk., 35, 29-35.

Wiliczkiewicz A., Skorupińska J., Jamroz D., 1987. Wpływ źródła pochodzenia włókna surowego na koncentrację i wykorzystanic białka w różnych odcinkach przewodu pokarmowego u rosnących gęsi. Zesz. Nauk. AR Wrocław. Zoot. XXX, 168, 139-149.

Wiliczkicwicz A., Jamroz D., Skorupińska J., 1989. W plyw pasz o różnej zawartości substancji strukturalnych na przewód pokarmowy i trawienie u rosnących gęsi. I. Zmiany długości i masy przewodu pokarmowego. Acta Agr. Silv., Zoot., 28, 193-205.

Wiliczkiewicz A.. 1988. Wpływ pochodzenia włókna surowego na zmiany składu treści jelit i trawienia wẹglowodanow strukturalnych u gęsi. Thesis. AR Wrocław.

Żebrowska H., 1985. Trawienie skrobi i włókna pasz pochodzenia zbożowego w poszczególnych odcinkach przewodu pokarmowego świń oraz wplyw włókna na te procesy. Thesis. PAN, Jabłonna. 


\section{STRESZCZENIE}

Wplyw pasz o różnej zawartości substancji strukturalnych na morfologiczne zmiany ścian jelit i strawność frakcji wlókna u gẹsi

Przeprowadzono dwa doświadczenia na 270 rosnących gessiach, kı́re karmiono pełnoporcjowymi mieszankami, różniącymi się zawartosicią frakcji węglowodanowych i strukturalnych. Poszczególne mieszanki zawieraly dużą jlość kukurydzy (50\%), suszu z traw (20\%). owsa (65\%), wysłodków buraczanych $(31 \%)$, żyta $(50 \%)$, jęczmienia $(60 \%)$, bobiku. grochu i śruty rzepakowej (po 20\%). Udzial tych pasz byl ustalony tak, aby ilość włókna surowego pochodzącego $z$ nich w mieszankach byla podobna, a pochodzącego $\%$ pas w micszance kontrolncj. Badano zmiany morfologiczne ścian jelita cienkiego i grubego po 1 i 2 godzinach po zadaniu paszy. Określono wspołczynniki strawności frakcji strukturalnych pasz.

Skarmianie mieszanek zawierających znaczna ilosic śruty owsianej $(65 \%)$, wyslodków buraczanych $(31 \%)$, a także suszu 7 traw $(21 \%)$ - pasz bogatych w celulozę $\mathrm{i}$ hemicelulozy, spowodowato u gęsi w wieku 8-ll tygodni zwiększenie grubości ścian jelita cienkiego i grubego, w tym głównie warstwy mięśniowej. Zwiękšne długości kosmków stwierd\%ono w jelicie grubym plaków karmionych mieszanką z suchymi wysłodkami buraczanymi. Skarmianie dużej ilości zawierającego pentozany żyta $(50 \%)$. spowodowało wzrost grubości warstwy śluzowej jelit, a skarmianic mieszanki ze śrutą rzepakową $(20 \%)$ - pocienienie ścian jelitowych. Stwierdzono niewielkie różnice w stopniu trawienia skladników strukturalnych $w$ obu ceçściach jelit. Celuloza trawiona była, zależnie od zestawu pasz, w 20-40, ADF w 18-38, a hemicelulozy w 40-57\%, przy czym największe różnice otrzymano u gęsi otrzymujących mieszankę zawierającą $65 \%$ śruty owsianej. 